\title{
Does Fairness Perceptions of Academic Staff Interfere with the Managerial Effectiveness?
}

\author{
Navneesh Tyagi, Priya Singh
}

\begin{abstract}
The growth of Indian higher education sector has brought about a shift from collegialism to managerialism and management issues have now become need of the hour for any institution. Thus managerial effectiveness of people in command is now considered as a preeminent ingredient of prosperity and endurance for these institutions of higher learning in this competitive era of global scenario. To understand thisdifferent influential factors to employee's behavior and attitude should be explored. Organizational justice is one of those important aspect that are used in explaining staff member's behaviors like job satisfaction, employee turnover intentions, organizational commitment etc. which are the prerequisites for managerial effectiveness. This study is an earnest effort to measure the influencethat organizational justice has on managerial effectiveness of chair holders i.e. director general, director, secretory, principal, and head of the departments in the higher education institutions. A structured questionnaire was used to collect data. Pearson correlation, structural equation modelling and stepwise multiple regression analysis were used. The findings revealed that faculty's perceptions of distributive justice, and interactional justice has a significant positive influence on managerial effectiveness while procedural justice depicted as not having significant positive influence on managerial effectiveness of heads in institutions of higher learning. It is observed that by concentrating on justice issues institutions and chair holders may be able to create a healthier and more productive workplace and chairpersons' overall managerial effectiveness can be enhanced.
\end{abstract}

Keywords: distributive justice, interactional justice, managerial effectiveness, Organizational justice,procedural justice.

\section{INTRODUCTION}

In Institutions of higher learning employee policies and programmes are formed on the centralized bases. While the educational policies and procedures play a significant role in the mission accomplishment of Institutions of Higher Learning,its heads are ultimately responsible for implementation of such policies and procedures. There appears a huge discrepancy among employees as regards distributional, proceduraland interactional fairness during the course of such implementations.Any dissatisfaction of employees in the workplace may ameliorate their distrust in organizational leadership. When leaders choose to ignore this distrust, employee morale and motivation suffers.

Revised Manuscript Received on October 31, 2019

* Correspondence Author

Ms. Navneesh Tyagi*, Assistant Professor, MIET Business School, Meerut, India. Email: nishuramantyagi@gmail.com

Dr.Priya Singh, Assistant Professor, IBS, Chaudhary Charan Singh University Campus, Meerut, India. Email: priyasingh.gkv@gmail.com

Higher education sector has witnessed a tremendous growth of 34 times in the number of universities and colleges from 20 in 1950 to 677 in 2014 [36]. Yet this sector is striving hard to discover new ways for survival and development of its institutions of higher learning. These Institutions are constantly guided by the persons in leadership positions (vice-chancellors, director, principal, registrar etc.) for future progression and achievement of its overall objectives. The continuous changes and increasing demands made on education sector have modified the roles and responsibilities of these institutional heads and an increasing requirement for the development of core managerial competencies are felt. [42] stated that higher education institutions are operating day by day on the same principles and requirements as the corporate and private sectors do and therefore competencies required for managerial effectiveness in institutional heads of higher education should also be like those in the corporate sector. They should act as an academic middle manager [27]. Managerial effectiveness is an important factor that is conceptualized in terms of competencies [50], the motivation for doing the work and work environment [49].In the context of education sector effectiveness is measured in terms of academic achievements, increase in teaching staff's effectiveness and improvement of student's outcome through managerial actions and behaviors of people at managerial leadership position. But they alonecannot transform everything and require people with determination and zeal. Therefore, it is essential to understand those behavioral variables that significantlycontribute in the formation of favorable behavior and attitude for instance employees' organizational commitment, turnover intentions, job satisfaction, organizational citizenship behavior, etc. Organizational justice is one of those aspects studied for explaining such behaviors and attitude.

\section{CONCEPTUAL FRAMEWORK}

A. Organizational Justice

Organizational Justice was depicted as the dominant factor for organizational life by [7].He observed its negativelysignificant influence on employees' turnover intentions [44]. Organizational justice is researched as an explanatory variable in human resource management that influences outcomes like organizational citizenship behavior, job satisfaction, organizational commitment behaviors, and andwithdrawal [6]. [11] and[10] described it as a social construct because individuals consider an act as just if it is perceivedsoby the individuals.Organizational justice builds trust, loyalty, commitment, and customer satisfaction, and improves job performance [8]. A positive and significant role of fairness perception in turn over intentions, organizational citizenship behaviour, andjob satisfaction was demonstrated by [39]. 


\section{Does Fairness Perceptions of Academic Staff Interfere with the Managerial Effectiveness?}

They suggested that managers should be thoughtful to their decisions and the choice of methods they use to arrive at these decisions as those would be so perceived by their staff members. Organizational justice have been categorised asProcedural Justice, Distributive Justice, and Interactional Justice [16],[57] and [32].[53]have also investigated a significant relationship between distributive justice, temporal justice,and interactional justicewith job satisfaction. Presence of interactional justice shows due respect to employees, introduction of consistent criteria, and provision of timely feedback with appropriate and sincere behaviour by supervisors. [30] indicated the mediating role of trust on significant positive influence of organizational justice on OCB. Researchers have identified several negative outcomes and counterproductive behaviors of perceived organizational injustice like unethical actions and retaliations [6]reduced performance ofjob[12], negative work attitude [13], stealing [21], holding important information and hiding errors [52], additional conflicts [9], and proclivity to implead against their employer.

\section{Distributive Justice}

It is the fairness in distribution and allocation of resources among people [25].Distributive justice include distribution of all sorts of attainments like wages, promotion duties, opportunities, status,and punishments/rewards among employees, on the basis of their similarities and differences [22],[19].

\section{Procedural Justice}

Procedural justice is the perception of fairness in means that are used to calculate the amount of benefits [20]. It reveals the role of justice perception in decision-making processes andin mutual relationships among employees withinan organization as well [33]. Participation of Employees in decision making procedures in the organizations and expectations of control are very much preferred in this regard [56].

\section{Interactional Justice}

Interactional Justice is the perception of fairness in interpersonal treatment by decision makers [4]. Perception of supportive and respectful supervisor dignities the subordinate's in the interaction processes [55]. They foundit as positively effective in terms of subordinates trust in their supervisors.It is also described as the interpersonal treatment that employees receive from their decision makers and its adequacy in explaining the formal decision making procedures [22].

\section{B. Managerial Effectiveness}

Managerial effectiveness as put forward by [46] is the level to which a manager or leader succeeds in achieving the output requirements of his position.

It is a result oriented phenomena; therefore those activities and functions which contribute to goal achievements and results need to be focused.Manager should be able to understand the psychological and social needs of employees so as to satisfy them because both perceptions and behaviours ofindividuals are related to each other. [5] proved that individuals who are warm-hearted, dynamic, persevering, pragmatic, stable, easy going, and emotionally mature have higher managerial effectiveness.

Managerial effectiveness is the ability of a manager to carry out activities related to his position in the course of achieving the organizational goals in relationsto current and future potential [26]. [40] defined it as the ability to analyze problems, cultural imperatives, and organizational design that produces results. [45] explained managerial effectiveness in terms of personality characteristic and the performance and results achieved by the manager. As the situations and needs of people keep on changing, managers should be highly adaptive for becoming an effective manager (Hersay and Blanchard, 1977). Collectively four aspects of management are covered by researchers in the functional paradigm of managerial effectiveness; people management, task management, strategic management, and relationship management.

\section{People Management}

Theories related to the management of people like human behaviour theory put emphasis on behaviour that is voluntary, learned, and a function of its consequences [54]. This involves obtaining trust of institutional members, image building, example setting, knowledge sharing, communications, building friendly atmosphere, conflict resolution, discussing important policy matters, encouraging staff members' participation and their welfare, fair allocation of work with well-defined roles and responsibilities are proven helpful to raise favourable responses from the people because of the consequences those responses will bring about.

\section{Task Management}

Task management was considered by different researchers in the form of work processes [51], worker motivation [34], and assumptions of management as theory $\mathrm{X}$ (people are lazy, dislike and avoid work) Theory $\mathrm{Y}$ (people are intelligent, creative, want to work) [35]. Managerial leaders should be effective in delegation, planning, management coordinating, motivating, appreciating and rewarding, creating conducive conditions, interacting and using tactics for task accomplishments.

\section{Strategic Management}

Effective managers must be forward looking and future oriented. They should maintain control over performance, i.e. control of work not workers. They should devise effective methods to perform training need analysis and look out for training opportunities in order to grow and develop staff members. While making a decision, managers must consider all aspects of the situation (Contingency theory) and act on the key aspects of the situation at hand [17].

\section{Relationship Management}

There is a situational correlation among task, behavior and the readiness of the group [28]. In liaison role, the leader exhibit formal and informal networks to gaincritical information related to the success of the organization [37]. [47]has identified a number of areas of focus in different academic leadershippositions that include managing relationships,policy formation, working with challenging staff, attending meetings, andinvolvement in various aspects of planning.

That is why an effective managers should interact regularly to make effective relations, work with staff members to reach decisions and be easily accessible.

It is evident from the above discussion that academic leaders have to focus upon employee behaviour (people management), work process and people attitude towards work (task management), liaising among them (relationship management) with a future orientation (Strategic management) to adapt to the changing situations. 
Managerial effectiveness and organizational justice are focused by various researchers individually and only a modicum of work has been done to emphasisthe relationship that organizational justice and managerial effectiveness have hence this study aimed at filling up this gap by exploring the direct impact of three dimensions of organizational justice on four dimensions of managerial effectiveness was conducted. The following model was proposed through this research:

\section{OBJECTIVE OF THE STUDY}

To investigatethe prediction ofmanagerial effectiveness through organizational justice in higher education institutions.

\section{HYPOTHESIS}

Ha1: Organizational Justice positively influences managerial effectiveness of heads of higher educationinstitutions.

Ha2: Dimensions of organizational justice positively influence People Management of heads in highereducationinstitutions.

Ha3: Dimensions of organizational justice positively influence Task Management of heads in higher educationinstitutions.

Ha4: Dimensions of organizational justice positively influence strategic Management of heads in higher educationinstitutions

Ha5: Dimensions of organizational justice positively influence relationship Management of heads in higher educationinstitutions.

\section{RESEARCH METHODOLOGY \\ A. SAMPLE}

To test the anticipated model a quantitative survey of Institutional heads viz. director, secretary, principal, and head of the department and their immediate staff membersfromselected institutions of higher learning inIndiawas conducted. A stratified proportionate sampling technique was used for sample selection and subjects were personally contacted via e-mail and personal administration of the structured questionnaire to 148respondents.Four states each from north, south, east, and westof India were used to select respondents. Total107 questionnaires were received that were foundstatistically usable for further analysis (response rate of 72 percent).The majority of respondents were married $(72.9 \%)$ males $(53.3 \%)$, within the age group of 30-40 years $(47.7 \%)$ working in Government Institutions from 0 years $(50.5 \%)$ and tenure of their present position was below 5 Years $(42.1 \%)$.

\section{B. TOOLS EMPLOYED}

A 20 items scale originally developed by [41] was used to measure organizational justice and itsdimensions i.e. procedural justice, distributive justice, and interactional justice.It assesses the perceptions of faculty members on a five point Likert scale. To study the managerial effectiveness a questionnaire was developed, which is a31 items, five point Liker scales that describe four dimensions of managerial effectiveness namely people management, task management, strategic management, and relationship management.
First of all the reliability and internal consistency for each scale and their dimensions were calculated separately.Managerial Effectiveness Questionnaire has 0.96 alpha value and all its dimensions have alpha values above 0.7. Organizational Justice Scale has got an overall alpha value of 0.92 and the alpha value for all its dimensions were also found to be more than 0.7. All the calculated values are abovethe acceptable limit of Cronbach alpha value above 0.7 [48] hence it can reasonably be asserted that both the scales are reliable to be used in the study.

\section{RESULTS AND DISCUSSIONS}

Institutional heads have to make decisions regarding vital aspects of job to emphasize depiction of commitment, trust and empathy in behavior among employees.

All the dimensions of organizational justice and managerial effectivenessaresignificantly and positively correlated. The correlation coefficient values vary fromlowest $(r=0.28)$ between people management and distributive justice to highest $(\mathrm{r}=0.92)$ between task management and organizational justice. The results reveal that as organizational justice perceptions of faculties increases managerial effectiveness also improves.

Ha1: Organizational Justice positively influences managerial effectiveness

To test Hypothesis Ha1 multiple regression was applied to estimate the magnitudeofvariance in managerial effectivenesscollectively explained by the three dimensions of organizational justice.

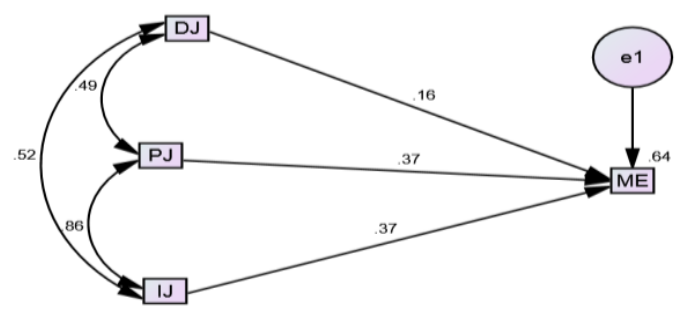

\section{FIG.1: Prediction of Managerial Effectiveness through Organizational Justice}

In fig.1single headed arrows indicate the standardized regression weights $(0.37,0.37$, and 0.16$)$ and double headed arrows represents correlation between the variables. Managerial effectiveness of heads is primarily influenced by interactional justice (.37), and procedural justice (.37) followed by distributive justice (.16). Thus hypotheses Ha1 is supported and the result is in line with the study of [18] demonstrating employee's acceptance for organizationalfairness to become more devoted to their organization and thus make more contributions to the institutions.

\section{(Table I, II, andIII should beplaced here)}

The squared multiple correlation of managerial effectiveness and organizational justice is 0.64 which means that $64 \%$ of variability in managerial effectiveness collectively is explained by the three dimensions of organizational justice, thus further supporting Hypothesis Ha1. 


\section{Does Fairness Perceptions of Academic Staff Interfere with the Managerial Effectiveness?}

Organizational justice led employees to prefer organizational objectives and goals upon personal goals. A fair treatment decrease employees strain [24] also it help in fulfilling four fundamental human needs according to the multiple needs model suggested in the study of [11] the need for a positive self-regard, control, belonging, and the meaning. The extent of relationship varies widely and independent variables are found highly correlated among themselves, therefore the genuine and critical predictorswere identified out of different dimensions of managerial effectivenessthrough stepwise multiple regression.

Ha2: Dimensions of organizational justice positively influence People Management

The dimensions of organizational justice were subjected to stepwise multiple regression on all dimensions of managerial effectiveness. The results of multivariate analyses for three dimensions of organizational justice revealed the prediction of competency in people management by interactional justice through multiple $\mathrm{R}$ value of0.447, $\mathrm{F}=26.259, \quad \mathrm{p}<0.05, \quad$ Beta=0.447, $\mathrm{R}$ Square $=0.200$, Procedural Justice predicted people managementthrough multiple $\mathrm{R}$ value of0.449, $\mathrm{F}=13.214$, $\mathrm{p}<0.01$, Beta=0.072, R Square=0.201. Distributive justice predicted people managementthrough multiple $\mathrm{R}$ value of 0.453, $\mathrm{F}=8.857, \mathrm{p}<0.01$, Beta=0.071, $\mathrm{R}$ Square=0.205. Three dimensions of organizational justice jointly explained $20 \%$ of people management competency of institutional heads. People Management involves employee participation, knowledge sharing, and welfare etc. by the heads. It effects employee's emotions and trust towards their head. The study of [6] and [3] also depicted theinfluence of employee's organizational justiceperception on trust of its people in their managers. Organizational justice has both positive and negative emotional consequences [38]. People at managerial leadership positions deal with these emotions associated with the workplace to manage their workforce. Greater perception of organizational justice will lead to higher emotional positivity that improves the commitment and dedication of staff members towards their work and organization that add to the effectiveness in their management.

Ha3: Dimensions of organizational justice positively influence Task Management

Task management in institutions is predicted by interactional justice through multiple $\mathrm{R}$ value of 0.802 , $\mathrm{F}=189.530, \quad \mathrm{p}<0.01, \quad$ Beta=0.802, $\mathrm{R} \quad$ Square=0.644, Procedural Justice predicted task managementthrough multiple $\mathrm{R}$ value of0.831, $\mathrm{F}=116.456, \mathrm{p}<0.01$, Beta=0.430, $\mathrm{R}$ Square $=0.691$. Distributive Justice predicted task managementthrough multiple $\mathrm{R}$ value of0.845, $\mathrm{F}=86.074$, $\mathrm{p}<0.01$, Beta $=0.180, \mathrm{R}$ Square $=0.715$. Three dimensions of organizational justice jointly explained $71 \%$ of task management in the institution. Task management involves delegation planning, motivating etc. by the heads to accomplish the task. If efficiency and productivity are involvedperformance is influenced by organizational justice [6] and improved justice perceptions increase both performance and productivity [31]. Thereby task management by institutional heads also improves.

Ha4: Dimensions of organizational justice positively influence strategic Management

Competency in strategic management is predicted by interactional justice through multiple $\mathrm{R}$ value of 0.502 , $\mathrm{F}=35.308, \mathrm{p}<0.01$, Beta $=0.502$, R Square $=0.252$, Procedural
Justice predicted strategic management through multiple $\mathrm{R}$ value of0.558, $\mathrm{F}=23.542, \quad \mathrm{p}<0.01, \quad$ Beta $=0.481, \quad \mathrm{R}$ Square $=0.318$. Distributive Justice predicted strategic management through multiple $\mathrm{R}$ value of0.573, $\mathrm{F}=16.792$, $\mathrm{p}<0.01, \mathrm{Beta}=0.152, \mathrm{R}$ Square $=0.327$. Three the dimensions of organizational justice jointly explained $32 \%$ of strategic management. Strategic management involves futuristic approach of the heads. In order to adapt employees should be motivated to acquire new skills and training by the heads. [15] depicted the relation of organizational justice with intrinsic motivation during performance of a task that assists as its own reward, pleasure, and enjoyment. Organizational justice ameliorates intrinsic motivation of employees to fulfil future demands of their heads and the institutions.

Ha5: Dimensions of organizational justice positively influence relationship Management

Relationship Management by institutional heads is predicted by interactional justice through multiple $\mathrm{R}$ value of0.740, F=126.944, p<0.01, Beta=0.740, R Square=0.810, Procedural Justice predicted relationship Management through multiple $R$ value of0.655, $F=98.914, p<0.01$, Beta $=0.646$, R Square=0.655. Distributive Justice predicted relationship Management through multiple $\mathrm{R}$ value of0.818, $\mathrm{F}=69.580, \mathrm{p}<0.01, \mathrm{Beta}=0.140, \mathrm{R}$ Square=0.670. Three dimensions of organizational justice jointly explained $13 \%$ of relationship Management. Relationship management involves conflict management and harmony in an organization or group.If senior managers gives utmost importance to use justice andserve organisation, employee become more dedicated and committed [6] that reduces conflicts and ensures harmony. Interactional Justice has been found to predict all the dimensions of managerial effectiveness most strongly. The hypothesis Ha2, Ha3, Ha4, and Ha5were retained at 0.01 level for predicting different dimensions of managerial effectiveness with respect to the three dimensions of organizational justice in institutions of higher learning. It was estimated that organizational justice predicted strategic management most strongly ( $\mathrm{R}$ square 0.43 ) followed by people management ( $R$ square 0.36 ) and task management (0.26). Institutions of higher learning need to focus on organizational justice issues primarily to enhance strategic management, people management, and task management effectiveness of institutional heads.

\section{CONCLUSION AND IMPLICATION}

Over the years researchers in the field of social sciences have focused on different aspects of workplace psychology. Managers must work to develop employee's perceptions of organizational justice. The present study was aimed at predicting the managerial effectivenessthrough organizational justice in higher educationinstitutions. This study revealed that there exist a significant influence of distributive justice, procedural justice and interactional justice on managerial effectiveness, which is consistent with the findings of [43] and the strength of relationship between variables, is medium to high. All the formulated hypotheses were approved through the analyses. Institutions which provide fairness in decision outcomes, formal decision making processes and interpersonal treatment by decision makers[23],[55] were found to possess managerial effectiveness of their heads.
Blue Eyes Intelligence Engineering \& Sciences Publication 
[14]had also reported the otherwise impact of organizational cynicism andinjustice in promoting employee's misbehavior within a public setting. This shows that motivation to serve in a managerial role at institution of higher learning without extrinsic rewards and respect may decline or even not exist at all. Materialistic gain from fairness perceptions of employeesimproves learning, knowledge, andunderstanding in this highly competitivesituationand also support people in managerial positions to move towards positive path of self, emotional literacy and alchemy to realize their potential and to achieve organizational goals [1] and [2] through and with people. Greater perceived organizational justice causes higher level of employee'scommitment and satisfaction with their job[29] which leave little space for conflicts and if arises can be sorted out more easily that provide uninterrupted flow of work towards achievement of organizational goals of managers.

It was seen that the institutional heads that possess high managerial effectiveness have got an important place in the institutions while those in low managerial effectiveness category cannot hope to survive in these institutions. This leads us to conclude that the managerial effectiveness of institutional leaders should be predicted in advance for estimating their stay in the institutions. The heads with less managerial effectiveness cannot be considered as a useful asset for any institution as theycannot survive in the competitive environment for long time. The study has institutional implications also in suggesting institutions that by providing fairness and justice to their staff members they can enhancethe ability of people in managerial leadership positions, to handle situations more constructively and to manage the resources efficiently.

\section{LIMITATIONS AND FUTURE IMPLICATIONS OF RESEARCH}

Limitations in this research that must be considered for future researches include small size of thesample which decreasesgeneralisability of its results. The findings are only generalisable toselected institutions of higher learning inIndia,reason being lack of homogeneity in culture across India. Further the study focused on institution of higher learning only.Future researchers may conduct their study in other parts of India and different levels of educational institutions for instance primary and secondary education institutions may also be included. Other variables which significantly contribute to work psychology of staffmembers in higher education institution may also be incorporated in future researches.

\section{REFERENCES}

1. H. A. Adekola, "Job and Personal Factors in work-burnout and work- family conflict amongpublic University Staff in south western Nigeria," 2006, unpublished Ph.D. thesis submitted to Olabisi Onabanjo University, Ago Iwoye, Ogun State-Nigeria. Retrieved from:http://www.hrmars.com/admin/pics/459.pdf

2. R. B. Ajala, "Drug abuse and misuse in the Nigerian society,"Nigerian school health journal, Vol. 18(1), 2006, pp. $45-$ 52.

3. S. Alexander \& M. Ruderman, "The Role of procedural and distributive justice in organizational behaviour, "Social Justice Research, vol. 1 (2), 1987, pp. 177-198.

4. M. L. Ambrose, M. A. Seabright, \& M. Schninke, "Sabotage in the workplace: The role of organizational injustice," Organizational behavior and human decision processes, vol. 89, 2002, pp. 947-965.

5. P. K. Chakrabarti and R. Kundu, "Personality Profile of Management Personnel," Psychological Studies, vol. 29(2), 1984, pp. 143-146.

6. Y.Cohen-Charasand P. E. Spector, "The role of Justice in Organizations: A meta-analysis,"Organizational Behavior and Human Decision Processes, vol. 86, 2001, pp. 278-321.

7. Cremer, "Procedural and distributive justice effects moderated by organizational identification,"Journal of Managerial Psychology, vol. 20(1), 2005, pp. 4-13.

8. R. Cropanzano, D. E. Bowen, S. W. Gilliland, "The Management of Organizational Justice," Academy of Management Perspectives People Management, 2007, pp. 34-49

9. R.Cropanzano and R.A. Baron, "Injustice and organizational conflict: The moderating effect of power restoration,"International Journal of Conflict Management, vol. 2(1), 1991, pp. 5-26.

10. R. Cropanzano, and J. Greenberg, "Progress in organizational justice: Tunneling through the maze," in C. Cooper, \&I. Robertson, Interactional Review of Industrial and Organizational Psychology, eds. New York: Wiley, 1997, pp.317-372.

11. R. Cropanzano and M. L. Ambrose, "Procedural and Distributive Justice are more similar than you think: A monistic perspective and research agenda," in Advances in Organizational Justice, 2001, J Greenberg \&R. Cropanzano eds. pp. 119-151. Stanford CA: Stanford University Press.

12. R.Cropanzano, C. A. Prehar, and P. Y. Chen, "Using social exchange theory to distinguish procedural from interactional justice,"Group \& Organization Management, vol. 27(3), 2002, pp. 324-351.

13. K.Daly, "Restorative justice: The real story,"Restorative Justice: Critical Issues, vol. 3(1), 2003, pp. 195.

14. H. Danaeefard and H. R. Baustani, "Injustice perceptions and employees misbehavior in the public organization: Exploration of mediating role of employee's cynicism to organization," Int. J. Hum. Capital Urban Manage., vol. 1(1),2016, pp. 9-18, DOI: 10.7508/ijhcum.2016.01.002

15. L. Deci, R. Koestner, and R. M. Ryan,"A meta-analytic review of experiments examining the effects of extrinsic rewards on intrinsic motivation,"Psychological Bulletin, vol. 125,1999,pp. $627-$ 668.Retrievedfrom:https://www.rug.nl/gmw/psychology/research/on derzoek_summerschool/firststep/content/papers/4.4.pdf

16. B.Erdogan, R. C. Liden, and L. M. Kraimer, "Justice and leader member exchange: The moderating role of organizational culture,"Academy of Management Journal, vol. 49, 2006, pp. 395406.Fiedler, "A Contingency Model of Leadership Effectiveness," in L. Berkowitz, Advances in Experimental Social Psychology, ed. New York, Academic Press, 1964.

17. R. Fischer, "Rewarding Employee Loyalty: An Organizational Justice Approach,"International Journal of Organisational Behaviour, Vol. 8 (3),2004, pp. 486-503

18. S. Foley, L. K. Deborah, and G. N. Powell, "The perceived glass ceiling and justice perceptions: an investigation of Hispanic law associates,"Journal of Management, vol. 28(4), 2002, pp. 471-496.

19. R. Folger, andM. A. Konovsky, "Effect of procedural and distributive justice on actions to pay raise decisions,"Academy of Management Journal, vol.32 (1), 1989, pp. 115-130.

20. J. Greenberg, andK. S. Scott, "Why do workers bite the hands that feed them? Employee theft as a social exchange process,"in Research in organizational behavior: An annual series of analytical essays and critical reviews, vol. 18,B.M. Staw and L.L. Cummings eds.1996, pp. 111-156.

21. J. Greenberg, "Organizational justice: Yesterday, today, and tomorrow,"J. Manage.Vol. 16(2), 1990, pp. 399-432.

22. J. Greenberg, "Stress Fairness to Fare No Stress: Managing Workplace Stress by Promoting Organizational Justice,"Organizational Dynamics, vol. 33(4), 2004, pp. 352-365.

23. J. Greenberg, "Losing sleep over organizational injustice: Attenuating insomniac reactions to underpayment inequity with supervisory training in interactional justice,"Journal of Applied Psychology, vol. 91, 2006, pp. 58-69.

24. J. Greenberg, andR. A. Baron, "Behaviour in organizations. Understanding and managing the human side of work," ed. 8. New Jersey: Prentice Hall, 2003.

25. S. Gupta, "Managerial effectiveness conceptual framework and scale development,"Indian Journal of Industrial Relations, vol. 31(3), 1996, pp. 392-409.

26. N. Hancock, andD. Hellawell, "Academic Middle Management in Higher Education: A Game of Hide and Seek?"Journal of Higher Education Policy and Management, vol. 25(1), 2003, pp. 5-12. 


\section{Does Fairness Perceptions of Academic Staff Interfere with the Managerial Effectiveness?}

27. P. Hersey, andR. H. Blanchard, "Management of organizational behavior: Utilizing human resources, "6th ed.New Jersey: Prentice Hall, 1993.

28. M. E. Ibrahim, and A. O. Perez, "Effects of Organizational Justice, Employee Satisfaction, and Gender on Employee Commitment: evidence from UAE,"International Journal of Business and Management, vol. 9(2), 2014, pp. 45-59.

29. H. Ismail, "Organizational Justice and Citizenship Behavior, the Mediating Role of Trust,"International Journal of Human Resource Studies, vol. 5(1), 2014, pp. 86-96.

30. J. Karriker, and M. Williams, "Organizational Justice and Organizational Citizenship Behavior: A Mediated Multifoci Model,'Journal of Management, vol. 35(1), 2009, pp. 112.

31. R. Klendauer, and J. Deller, "Organizational Justice and manageria commitment in corporate mergers,"Journal of Managerial Psychology, vol. 24(1), 2009, pp. 29-45.

32. M. A. Korgaard, and H. J. Sapienza, "Toward an Integration of Agency and Procedural Justice Theories,"in Emerging Perspectives on Managing Organizational, S. W. Gilliland, D. D. Steiner D. P. Skarlicki eds.Charlotte, NC: Information Age Publishing, 2002, pp. $3-$ 34H. Maslow, "Motivation and personality"2nd ed., New York: Harper \& Row, 1970

33. McGregor, "The human side of enterprise," New York: McGrawHill, 1960.

34. MHRD, 2017, Retrieved from http://mhrd.gov.in/university-andhigher-education

35. H. Mintzberg, "The structuring of organizations: A synthesis of the research," Englewood Cliffs, N.J: Prentice-Hall, 1979.

36. K. Murphy, andT. Tyler, "Procedural justice and compliance behaviour: The mediating role of emotions,"European Journal of Social Psychology, vol. 38, 2008, pp. 652-668.

37. H. Nadiri, and C. Tanova, "An investigation of the role of justice in turnover intentions, job satisfaction, and organizational citizenship behavior in hospitality industry,"International journal of hospitality management, vol. 89, 2010, pp. 33-41.

38. S.K. Nair, and S. Yuvraj, "Locus of control and managerial effectiveness: A study of private sector managers,"Indian Journal of Industrial Relation, vol. 36(1), 2000, pp. 41-52.

39. P. Niehoff, and R. H. Moorman, "Justice as a mediator of the relationship between methods of monitoring and psychological wellbeing,"Academy of management journal,1993, pp. 527-56

40. Potgieter, J. Basson, and M. Coetzee, "Management competencies for the development of heads of department in the higher education context: a literature overview,"South African Journal of Labour Relations, vol. 35(1), 2011, pp. 81-103.

41. G. Rana, and R. Rastogi, "Organizational justice enhancing managerial effectiveness in terms of activities of his position, achieving results and developing further potential,"Research on humanities and social sciences, vol. 5(1), 2015, pp. 24-31

42. Rastgar, "A Study of the Relationship between Organizational Justice and Turnover Intentions: Evidence from Iran,"International Journal of Research in Organizational Behavior and Human Resource Management, vol. 1(2), 2013, pp. 1-10.

43. R. Rastogi, and V. Dave, "Managerial Effectiveness: A function of personality type and organizational components,"Singapore Management Review, vol. 26, 2004, pp. 79-87.

44. W. J. Reddin, "Managerial Effectiveness," New York: McGraw-Hill, 1970.

45. Scott, H. Coates, and M. Anderson, "Learning leaders in times of change: academic leadership capabilities for Australian higher education. Sydney," University ofWestern Sydney and Australian Council for Educational Research,2008.Available from:www.altc.edu.au/resource-earning-leaders-change-uws-2008

46. U. Sekaran, "Research Methods for business: Skill building approach," New York: John Wiley and Sons, 2003.

47. R. Sethi, and C. Y. Nicholson, "Structural and contextual correlates of charged behavior in product development teams,"Journal of Product Innovation Management, vol. 18, 2001, pp. 154-168.

48. F. Shipper, J. Kincaid, D. M. Rotondo, and R. C. Hoffman, "A cross cultural exploratory study of the linkage between emotional intelligence and managerial effectiveness,"The International Journal of Organizational Analysis, vol. 11(3), 2003, pp. 171-191.

49. F. W. Taylor, "The Principles of Scientific Management," New York Harper Bros, 1911

50. L.K. Trevino and G. R. Weaver, "Organizational justice and ethics program 'follow-through': influences on employees' harmful and helpful behaviour,"Business Ethics Quarterly, vol. 11(4), 2001, pp. 651-671

51. S. Usmani, and S. Jamal, "Impact of distributive justice, procedura justice, interactional justice, temporal justice, special justice on job satisfaction of banking employees,"Review of integrative busines and economic research, vol. 2(1), 2013, pp. 351-384.

52. V. H. Vroom, "Work and motivation," New York: Wiley, 1964

53. Wat and M. A. Dan Shaffer, "Equity and relationship quality influences on organizational citizenship behavior,"Journal of Personnel Review, vol. 34(4), 2005, pp. 406-422.

54. M. Yuvuz, "The effects of teachers' perception of organizational justice and culture on organizational commitment,"AfricanJournal of Business Management, vol. 4(5), 2010, pp. 695-701. Retrieved from http://www.academicjournals.org/AJBM

55. L. Zhang, T. Nie, and Y. Luo, "Matching organizational justice with employment modes strategic human resource management perspective,"Journal of Technology Management in China, vol. 4(2), 2009, pp.180-187. 


\section{APPENDIX}

Table I: Stepwise multiple regression analysis showing Managerial Effectiveness as dependent variable with the dimensions of Organizational Justice (N-107)

\begin{tabular}{|c|c|c|c|c|c|c|c|}
\hline & $\mathbf{R}$ & R Square & Adjusted R Square & SEM & F-value & D.F & B Value \\
\hline \multicolumn{8}{|c|}{$\begin{array}{l}\text { Dependent Variable: } \\
\text { 1. People Management }\end{array}$} \\
\hline $\mathrm{IJ}$ & $.447^{\mathrm{a}}$ & .200 & .192 & 10.320 & 26.259 & 105 & .447 \\
\hline IJ, PJ & $.449^{\mathrm{b}}$ & .201 & .186 & 10.387 & 13.114 & 104 & $.0385, .072$ \\
\hline IJ, PJ, DJ & $.453^{\mathrm{c}}$ & .205 & .187 & 10.360 & 8.857 & 103 & $.357, .062, .071$ \\
\hline \multicolumn{8}{|l|}{ 2. Task Management } \\
\hline IJ & $.802^{\mathrm{a}}$ & .644 & .640 & 8.489 & 189.530 & 105 & .802 \\
\hline IJ, PJ & $.831^{\mathrm{b}}$ & .691 & .681 & 7.937 & 116.456 & 104 & $.432, .430$ \\
\hline IJ, PJ, DJ & $.845^{\mathrm{c}}$ & .715 & .707 & 7.666 & 86.074 & 103 & $.361, .403, .180$ \\
\hline \multicolumn{8}{|c|}{ 3. Strategic Management } \\
\hline $\mathrm{IJ}$ & $.502^{\mathrm{a}}$ & .252 & .245 & 2.598 & 35.308 & 105 & .502 \\
\hline IJ, PJ & $.558^{\mathrm{b}}$ & .318 & .298 & 2.504 & 23.542 & 104 & $.087, .481$ \\
\hline IJ, PJ, DJ & $.573^{\mathrm{c}}$ & .328 & .309 & 2.486 & 16.792 & 103 & $.027, .459, .152$ \\
\hline \multicolumn{8}{|c|}{ 4. Relationship Management } \\
\hline IJ & $.740^{\mathrm{a}}$ & .547 & .543 & 2.103 & 126.944 & 105 & .740 \\
\hline IJ, PJ & $.810^{\mathrm{b}}$ & .655 & .649 & 1.844 & 98.914 & 104 & $.184, .646$ \\
\hline IJ, PJ, DJ & $.818^{\mathrm{c}}$ & .670 & .660 & 1.814 & 69.580 & 103 & $.129, .625, .140$ \\
\hline
\end{tabular}

a. Predictors: (Constant), DJ b. Predictors: (Constant), DJ, PJ c. Predictors: (Constant), DJ, PJ, IJ

Table II: Model Summary of linear regression

\begin{tabular}{|l|r|r|r|r|r|}
\hline Model & R & R Square & Adjusted R Square & \multicolumn{1}{c|}{ Std. Error of the Estimate } \\
\hline 1 & $.802^{\mathrm{a}}$ & .643 & F change & Sig. \\
\hline
\end{tabular}

a. Predictors: (Constant), IJ, DJ, PJ

Table III: Beta Coefficientsof linear regression

\begin{tabular}{|c|c|c|c|c|c|c|}
\hline \multicolumn{2}{|c|}{ Model } & \multicolumn{2}{|c|}{ Unstandardized Coefficients } & \multirow{2}{*}{$\frac{\text { Standardized Coefficients }}{\text { Beta }}$} & \multirow[t]{2}{*}{$\mathrm{T}$} & \multirow[t]{2}{*}{ Sig. } \\
\hline & & $\mathrm{B}$ & Std. Error & & & \\
\hline \multirow{4}{*}{1} & (Constant) & 11.055 & 9.078 & & 1.218 & .226 \\
\hline & DJ & 1.183 & .509 & .161 & 2.321 & .022 \\
\hline & PJ & 1.935 & .613 & .367 & 3.159 & .002 \\
\hline & IJ & 1.204 & .391 & .365 & 3.076 & .003 \\
\hline
\end{tabular}

a. Dependent Variable: ME

\section{AUTHORS PROFILE}

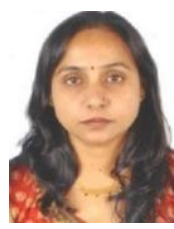

Ms. Navneesh Tyagi is an assistant professor in the Department of business and management studies, MIET Group of Institutions, Meerut, India. She is resourceful professional with 7 years of academic career in teaching and research. She has taught various subjects like Human Resource Management and Organizational Behavior and guided various projects to postgraduates and Undergraduates. She is Pursuing $\mathrm{PhD}$ in management and has qualified UGC NET (Industrial Relation) 2013 and UGC NET (Management) 2012. She has two post-graduation degrees of Master of Commerce (M.Com) and Master of Business Administration (MBA). She is a certified trainer of AIMA Bizlab. She has attended participated in various FDPs and contributed various research papers in different national and international conferences and journals. She is a member of various international, national, and local management associations. Her areas of interest are Marketing Management, Human Resource Management, Organisational Behaviour, Marketing of Services, General Management, Team Building \& Leadership, Training \& Development and Research Methodology.

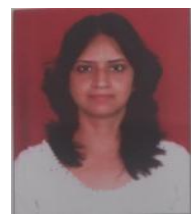

Dr. Priya Singh is an Assistant Professor in Institute of Business Studies, Chaudhary Charan Singh Universty Campus, Meerut, U.P. India. She did $\mathrm{PhD}$ in management after doing her MBA with dual specialisation in Marketing and HRM. She is UGC-NET qualified in management and had been selected as ICSSR Doctoral fellow during her PhD for the period 2015-16. She has more than 7 years of experience in teaching and research work. She has taught various subjects to BBA and MBA students and has guided projects at under-graduate and graduate level. She has presented and published various research papers in national and inter-national journals, seminars \& conferences. She is a certified trainer of AIMA Bizlab. She has attended participated in various FDPs Her area of interest are Marketing Management, Human Resource Management, Organisational Behaviour, Marketing of Services, General Management, Team Building \& Leadership, Training \& Development and Research Methodology. 